\title{
Anaesthetic Management of a Child with Arthrogriposis Multiplex Congenita
}

\author{
Asthana $V^{1 *}$, Jindal P1, Mehrotra S2 ${ }^{2}$ Juyal A ${ }^{3}$ \\ ${ }^{1} \mathrm{MD}$, Professor, Department of Anesthesiology, India \\ ${ }^{2} \mathrm{MD}$, Ex- Resident, Department of Anesthesiology, India \\ ${ }^{3}$ MS, Professor, Department of Orthopeadic Surgery, India
}

Case Report

Volume 1 Issue 3

Received Date: September 13, 2016

Published Date: October 19, 2016

*Corresponding author: Veena Asthana, Professor, Department of Anesthesiology

HIMS,SRHU University, Swami Rama Nagar, Jolly Grant, Dehradun, India Tel: +91971929195; E-mail: drvasthaana@yahoo.co.in

\section{Abstract}

An uncommon congenital condition called Arthrogriposis multiplex congenita is characterized by micrognathia, limited mandibular opening and multiple joint contractures which contribute to difficult airway and other anaesthesia problems. We describe the anesthetic management of a child with arthrogriposis multiplex congenital syndrome undergoing repair of club feet.

Keywords: Anesthetic management; Arthrogriposis multiplex congenital; Difficult airway

\section{Introduction}

Arthrogriposis multiplex congenita is an uncommon non progressive condition characterized by multiple joint contractures [1]. Contractures involve the extremities of patients with Arthrogripozis multiplex congenita. It affects maxillofacial area causing limited mandibular due to temporomandibular joint involvement and microstomia [2,3]. The incidence of this syndrome is 1 per 3000-10000 live births [1,2]. Arthrogripozis multiplex congenita also effects other organ systems such as cardiovascular, respiratory, gastrointestinal, genitourinary and locomotor system [4]. Patients with Arthrogripozis multiplex congenita require anesthesia during surgical procedures to correct the orthopedic deformities or the organ systems associated with the disease process. They have difficult intravenous access, airway management and regional anesthesia as well as the implications of the underlying neuromuscular disorder [4].

\section{Case Report}

A 5 year old $20 \mathrm{~kg}$ female infant presented for repair of club feet. The birth history revealed that the infant was born full term with multiple contractures so a diagnosis of arthrogriposis multiplex congenita was made after 3months of birth. She underwent previous surgeries for repair of club feet and tendon release. Physical examination of an infant revealed severe multiple joint contractures of all limbs and marked micrognathia (Figure 1). 


\section{Anaesthesia \& Critical Care Medicine Journal}

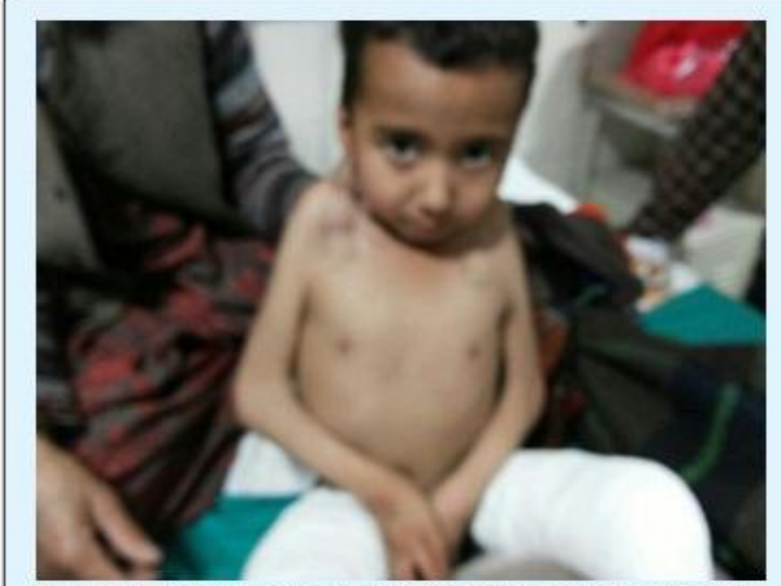

Figure 1: Photograph of a child with Arthrogriposis Multiplex congenital.

The standard monitors were applied and as the child was co-operative 22-gauge scalp peripheral intravenous catheter was secured without much difficulty. In view of difficult and failed intubation we kept standby tracheotomy ready as we had limitations of peadtric fiber optic bronchoscope ,smaller size fast tract LMA and video laryngoscope in our set up .After 5 minutes of preoxygenation, anesthesia was induced by injection propofol $\left(2.5 \mathrm{mg} \mathrm{kg}^{-1}\right)$ and fentanyl $\left(1 \mu \mathrm{g} \mathrm{kg}^{-1}\right)$. Ease of mask ventilation was checked and after neuromuscular block with atracurium $\left(0.5 \mathrm{mg} \mathrm{kg}^{-1}\right)$ laryngoscopy was performed. The laryngoscopic grade was modified Cormack Lehane grade III so only the epiglottis could be visualized. The first intubation attempt was unsuccessful. Following a failed intubation attempt, in the third attempt patient was intubated with a size 3 uncuffed or tracheal tube using paraglossal approach. A straight blade laryngoscope was introduced from the right corner of the mouth along the groove between the tongue and the tonsil, using leftward and anterior pressure by displacing the tongue to the left side. The tip of laryngoscope blade was made to pass posterior to the epiglottis. Published literature documents rotation of the neck and manipulation of the cricoid cartilage to improve the laryngoscopic view. Immediately after the insertion, positioning was confirmed by breath sounds, wave form capnography and end tidal carbon dioxide. Although intubation had been difficult, the patient did not become hypoxic at any stage. Maintenance of anesthesia was done using Dexmedetomidine infusion supplemented with fentanyl. At the end of 1.5 hours of anesthesia for postoperative pain relief caudal block was given and patient was extubated without complications.

\section{Discussion}

Our case report defines problems of general anesthesia in a child with arthrogripozis multiplex congenita. The primary concern in such cases is the airway involvement thereby making direct laryngoscopy and endotracheal intubation difficult [2-5].

The commonest maxillafacial findings are reduced mandibular opening, micrognathia, a high arced palate, inadequate musculature of the oropharyngeal complex, restricted tongue protusion and cleft palate. The incidence of maxillofacial involvement in AMC has been reported to be 22-25\%. Among Diamond-Blackfan Anaemia -affected children, $10-40 \%$ also have craniofacial malformations, although Katircioglu et al., did not encounter any difficult airway [6].

Literature shows that these patients may be more susceptible to the respiratory depressant effects of various intravenous and inhalation anaesthetics $[1,2,4]$. Moreover respiratory problems in the perioperative period may be related to associated myopathy, pulmonary hypoplasia and spine deformities [1,4,7-9]. In our case we did not faced postoperative atelectasis or a restrictive respiratory pattern, as we closely monitored for postoperative respiratory function.

Review of literature offers contradictory reports on the choice of neuromuscular agent. In patients with an identified underlying myopathic disorder, there may be an hyperkalemic response, and patients may be susceptible to malignant hyperthermia. However, Baires et al. reviewed 67 patients with arthrogripozis multiplex congenita and found no episodes of $\mathrm{MH}$ with exposure to known triggering agents [10]. But to be cautious we avoided succinylcholine and volatile anesthetics and used atracurium for maintenance. Short acting muscle relaxant like mivacurium has been used in a few cases .but as it is not available we did not use it. 


\section{Anaesthesia \& Critical Care Medicine Journal}

\begin{tabular}{|c|c|c|}
\hline $\begin{array}{l}\text { Difficult } \\
\text { airway }\end{array}$ & $\begin{array}{l}\text { micrognathia, high arched palate, } \\
\text { cervical spine instability (under development of } \\
\text { first and second cervical vertebra) }\end{array}$ & $\begin{array}{l}\text { Keep difficult airway cart ready } \\
\text { Follow difficult intubation algorithm } \\
\text { Keep help standby }\end{array}$ \\
\hline Myopathy & $\begin{array}{l}\text { increased sensitivity and prolonged duration of } \\
\text { neuromuscular blockers }\end{array}$ & $\begin{array}{l}\text { Use neuromuscular drugs judiciously } \\
\text { Neuromuscular monitoring should be done }\end{array}$ \\
\hline $\begin{array}{l}\text { Malignant } \\
\text { hyperthermia } \\
\text { (MH) }\end{array}$ & (some variants have been associated with $\mathrm{MH}$ ) & $\begin{array}{c}\text { avoid triggering agents } \\
\text { such as Succinyl choline and inhalational } \\
\text { anesthetic agents }\end{array}$ \\
\hline $\begin{array}{l}\text { Cardio- } \\
\text { respiratory }\end{array}$ & $\begin{array}{c}\text { increased sensitivity to induction } \\
\text { agents. }\end{array}$ & $\begin{array}{c}\text { They may have a high risk of postoperative } \\
\text { respiratory depression and are prone to } \\
\text { aspiration }\end{array}$ \\
\hline $\begin{array}{l}\text { Difficult } \\
\text { regional } \\
\text { blockade }\end{array}$ & $\begin{array}{c}\text { Due to existing spinal changes, regional } \\
\text { anaesthesia methods close to the spinal cord are } \\
\text { partly described to be impossible, difficult access } \\
\text { to nerves due to joint contractures. }\end{array}$ & $\begin{array}{c}\text { Performed at the hand of expert, USG guided } \\
\text { nerve block }\end{array}$ \\
\hline $\begin{array}{l}\text { Difficult IV } \\
\text { access }\end{array}$ & $\begin{array}{l}\text { reduced subcutaneous tissue and } \\
\text { tense skin. }\end{array}$ & \\
\hline $\begin{array}{c}\text { Difficult } \\
\text { positioning }\end{array}$ & joint contractures and reduced muscle mass & Adequate padding to be done \\
\hline
\end{tabular}

As the first two attempts failed using the conventional method we used paraglossal approach. The advantage of using this technique is that structures in the midline which hamper the laryngeal view in the anterior airwayline are avoided. In summary, this report highlights the anaesthetic management of arthrogripozis multiplex congenita, which may be complicated by a difficult airway because of micrognathia. Appropriate preoperative evaluation and preparation is required for successful outcome.

\section{References}

1. Thompson GH, Bilenker RM (1985) Compherensive management of artrogripozis multiplex congenita. Clin Orthop194: 6-14.

2. Epstein JB, Wittenberg GJ (1987) Maxillofacial manifestations and management of arthrogryposis: literature review and case report. J Oral Maxillofac Surg 45(3): 274-279.

3. Steinberg B, Nelson VS, Feinberg SE, Calhoun C (1996) Incidence of maxillofacial involvement in arthrogryposis multiplex congenita. J Oral Maxillofac Surg 54(8): 956-959.

4. Oberoi GS, Kaul HL, Gill IS, Batra RK (1987) Anaesthesia in arthrogryposis multiplex congenita: case report. Can J Anaesth 34(3): 288-290.
5. Thomas JA, Chiu-Yeh M, Moriconi ES (2001) Maxillofacial implications and surgical treatment of arthrogryposis multiplex congenita. Compend Contin Educ Dent 22(7): 588-592.

6. Katircioglu K, Ozturk Kavrut N, Ozkalkanli MY, Savaci $S$ (2008) Anesthetic management in a child with Diamond-Blackfan anemia. Paediatr Anaesth J 18(6): 574-575.

7. Martin S, Tobias JD (2006) Peroperative care of the child with athrogryposis. Pediatr Anesth 16(1):31-37.

8. Nguyen NH, Morvant EM, Mayhew JF (2000) Anesthetic management for patients with arthrogryposis multiplex congenita and severe micrognathia: case reports J Clin Anesth 12(3): 227230.

9. Yingsakmongkol W, Kumar SJ (2000) Scoliosis in arthrogryposis multiplex congenita: results after nonsurgical and surgical treatment. J Pediatr Orthop 20(5): 656-661.

10. Baines DB, Douglas ID, Overton JH (1986) Anaesthesia for patients with arthrogryposis multiplex congenita: what is the risk of malignant hyperthermia? Anaesth Intensive Care 14(4): 370372.

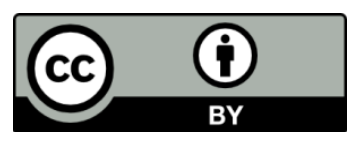

